\title{
Usefulness of a Pericardial Friction Rub After Thrombolytic Therapy During Acute Myocardial Infarction in Predicting Amount of Myocardial Damage
}

\author{
Thomas C. Wall, MD, Robert M. Califf, MD, Lynn Harrelson-Woodlief, MS, Daniel B. Mark, MD, \\ MPH, Michael Honan, MD, Charles W. Abbotsmith, MD, Richard Candela, MD, Eric Berrios, RN, \\ Harry R. Phillips, MD, Eric J. Topol, MD, and the TAMI Study Group
}

\begin{abstract}
To evaluate the clinical incidence and outcomes of patients with pericarditis after thrombolytic therapy, 810 patients were prospectively studied during acute myocardial infarction (AMI). Pericarditis was defined as the presence of a pericardial friction rub during the hospital course. Only $5 \%$ of patients developed a rub during AMI, a low percent compared with that in the prethrombolytic era. A pericardial friction rub more often occurred in the setting of an anterior wall AMI. Patients with, compared to those without, a pericardial friction rub had lower ejection fractions ( 45 vs $51 \%, p=0.002$ ); worse regional left ventricular function $(-3.2$ vs 2.7 , standard deviation per chord); higher in-hospital mortality (15 vs $6 \%, p=0.056)$; a higher frequency of power failure ( 83 vs $57 \%$ ); a higher frequency of anterior wall location of the AMI $(53 \%$ of cases, p $=0.002$ ); and a higher frequency of 3-vessel disease. Therefore, although the frequency of a pericardial friction rub was low (5\%) compared with that in the prethrombolytic era, its occurrence denotes more extensive myocardial damage with a worse clinical outcome. Perhaps with successful reperfusion of the infarct-related vessel, transmural myocardial necrosis is prevented and with it the development of pericarditis. Cardiac tamponade did not occur clinically in any patient who developed a pericardial friction rub.
\end{abstract}

(Am J Cardiol 1990;66:1418-1421)

From the Division of Cardiology, Department of Medicine, Duke University Medical Center, Durham, North Carolina; The University of Michigan Medical Center, Ann Arbor, Michigan; Riverside Methodist Hospital, Columbus, Ohio; and Christ Hospital, Cincinnati, Ohio. This study was supported in part by Research Grant HS05635 from the Agency for Hcalth Care Policy and Research, Rockville, Maryland, and Research Grant HL36587 from the National Heart, Lung, and Blood Institute, Bethesda, Maryland. Manuscript received May 10, 1990; revised manuscript received and accepted August 1, 1990.

Address for reprints: Thomas C. Wall, MD, Duke University Medical Center, Box 3484, Durham, North Carolina 27710.
$\mathrm{B}$ efore the era of thrombolytic therapy, pericarditis in acute myocardial infarction (AMI) was reported to occur in approximately 7 to $20 \%$ of patients. ${ }^{1-6}$ Based on clinical and pathologic studies, the presence of extensive transmural necrosis was believed to be a prerequisite for the development of pericardial inflammation. ${ }^{7}$ Hospital and long-term mortality has been reported to be higher in conservatively treated patients with evidence of pericarditis after AMI. ${ }^{3-5}$ By achieving early reperfusion, the use of thrombolytic therapy may prevent progression to transmural necrosis, thereby reducing the risk of developing pericarditis. ${ }^{8}$ Once an inflammatory reaction has developed, the risk of the development of hemorrhagic pericardial tamponade may be increased. ${ }^{9}$ Although pericarditis has been previously reported to occur less frequently in patients given thrombolytic therapy in the setting of AMI, ${ }^{10-12}$ the frequency and clinical outcomes of pericarditis after this treatment has not been systematically studied. This study reports the cumulative Thrombolysis and Angioplasty in Myocardial Infarction (TAMI) study's experience with pericarditis in the setting of thrombolytic intervention.

\section{METHODS}

Patients: Patients with AMI complicated by pericarditis were identified in the TAMI trials 1 through 3 and in the Urokinase Pilot Study at Duke University Medical Center. Pericarditis was strictly defined as the presence of a pericardial friction rub on auscultation on physical examination at any time during the patient's hospitalization. The patients were examined at least daily by the attending physician and study nurses.

As previously described, patients with AMI were prospectively enrolled in trials of intravenous thrombolytic therapy if they met the standard treatment criteria. ${ }^{13-16}$ Briefly, inclusion criteria included: (1) symptoms consistent with an AMI for 30 minutes' duration without response to sublingual nitroglycerin, (2) STsegment elevation of $>1 \mathrm{~mm}$ in $\geq 2$ contiguous electrocardiographic leads, (3) onset of chest discomfort within 6 hours of the time of thrombolytic therapy administration, and (4) age <76 years. Usual exclusion criteria included: (1) no bleeding diathesis, (2) absence of cardiogenic shock, and (3) no prior coronary artery bypass surgery. 


\begin{tabular}{|c|c|c|}
\hline Study & Pharmacologic Regimen & Patients \\
\hline TAMI 1 & rt-PA $(150 \mathrm{mg}) \pm$ PTCA & 385 \\
\hline TAMI 2 & rt-PA + urokinase (variable doses) & 147 \\
\hline TAMI 3 & rt-PA $(135-150 \mathrm{mg}) \pm$ heparin & 175 \\
\hline Urokinase & Urokinase ( 3 million units) & 102 \\
\hline Total & & 810 \\
\hline \multicolumn{3}{|c|}{$\begin{array}{l}\text { PTCA }=\text { percutaneous transiuminal coronary angioplasty; rt-PA = recombinant } \\
\text { tissue-type plasminogen activator; TAMI }=\text { Thrombolysis and Angioplasty in Myocar- } \\
\text { dial Infarction trial. }\end{array}$} \\
\hline
\end{tabular}

\begin{tabular}{|ccc|}
\hline $\begin{array}{l}\text { TABLE II } \\
\text { Incidence }\end{array}$ & & \\
\hline & No. of & Patients Developing \\
Study & Patients & Pericardial Rub \\
\hline TAMI 1 & 386 & $21(5 \%)$ \\
TAMI 2 & 147 & $1(1 \%)$ \\
TAMI 3 & 175 & $16(9 \%)$ \\
Urokil IdSe & 102 & $2(2 \%)$ \\
Total & 810 & $40(5 \%)$ \\
\hline TAMI = Thrombolysis and Angioplasty in Myocardial Infarction trial. \\
\hline
\end{tabular}

Therapeutic regimens: The 4 thrombolytic therapy trials with their respective pharmacologic interventions are displayed in Table I. ${ }^{13-16}$ As previously reported, after immediate catheterization, all patients were treated with standard therapy including lidocaine, oxygen, morphine as needed for pain and nitrates either topically or intravenously. Aspirin, $325 \mathrm{mg} /$ day, was also administered along with a continuous infusion of intravenous heparin to maintain the partial thromboplastin time at 2 times the control value. This infusion was continued until repeat catheterization at 7 to 10 days. Beta blockers were not added to the medical regimen unless clinically indicated for systemic hypertension, supraventricular tachyarrhythmias or noncardiac disorders (e.g., migraine headaches). Patients were also treated with calcium antagonists 3 times a day. Other medications, including antiarrhythmic agents, were used at the discretion of the clinician. No other antiplatelet agents such as dipyridamole were used routinely.

Data analysis: Case report forms were completed by the clinical research nurse coordinators and reviewed by the principal investigator at each site before submission to the Duke Data Coordinating Center. The data were verified independently by study monitors from review of the clinical records.

Throughout the clinical trials reviewed in this report, a consistent database was maintained to allow for assurance about variable definition and recording of events. Values for continuous variables are presented as mean +1 standard deviation (SD) and for discrete variables values are presented as percentages. For discrete variables, comparisons were made by the chi-square test or the Fisher's exact test and by $t$ tests for continuous variables. All $\mathrm{p}$ values presented are 2 -sided.

\section{RESULTS}

The frequencies of pericardial friction rub for the different studies are listed in Table II. Of 810 patients

\begin{tabular}{|c|c|c|}
\hline & $\begin{array}{l}\text { Pericardial Rub } \\
(n=40)\end{array}$ & $\begin{array}{l}\text { No Pericardial Rub } \\
(n=770)\end{array}$ \\
\hline Age (years)* & $56(46-65)$ & $57(49-65)$ \\
\hline Men/women & $36 / 4$ & $614 / 156$ \\
\hline Weight (kg)* & $84(72-93)$ & $82(73-91)$ \\
\hline \multicolumn{3}{|l|}{ Coronary risk factors $+(\%)$} \\
\hline Systemic hypertension & 43 & 42 \\
\hline Diabetes mellitus & 8 & 16 \\
\hline Hypercholesterolemia & 5 & 13 \\
\hline Cerebrovascular disease & 3 & 2 \\
\hline Peripheral vascular disease & 5 & 5 \\
\hline $\begin{array}{l}\text { Family history of premature } \\
\text { coronary artery disease }\end{array}$ & 43 & 46 \\
\hline Cigarette smoking & 60 & 64 \\
\hline
\end{tabular}

\begin{tabular}{|c|c|c|}
\hline & $\begin{array}{l}\text { Pericardial Rub } \\
(n=40)\end{array}$ & $\begin{array}{l}\text { No Pericardial Rub } \\
(n=770)\end{array}$ \\
\hline \multicolumn{3}{|l|}{ AMl location (\%) } \\
\hline Anterior & $23(57)$ & $308(40)$ \\
\hline Inferior & $17(43)$ & $162(60)$ \\
\hline \multicolumn{3}{|l|}{ Infarct-related artery $(\%)$} \\
\hline Left main & $1(2)$ & $1(0.5)$ \\
\hline Left anterior descending & $20(50)$ & $288(37)$ \\
\hline Left circumflex & $3(8)$ & $101(13)$ \\
\hline Right & $14(35)$ & $358(47)$ \\
\hline Graft & $1(2)$ & $4(0.5)$ \\
\hline Undetermined & $1(2)$ & $18(2)$ \\
\hline \multicolumn{3}{|l|}{$\begin{array}{l}\text { No. of coronary arteries } \\
\text { narrowed } 50 \% \text { in } \\
\text { diameter }(\%)\end{array}$} \\
\hline 0 & $4(10)$ & $59(8)$ \\
\hline 1 & $16(40)$ & $362(47)$ \\
\hline 2 & $7(17)$ & $217(28)$ \\
\hline 3 & $12(30)$ & $126(16)$ \\
\hline Left main & $1(3)$ & $6(1)$ \\
\hline \multicolumn{3}{|l|}{$\begin{array}{l}\text { TIMl grade } 90 \text { minutes } \\
\text { consensus }(\%)\end{array}$} \\
\hline Patent & $28(72)$ & $539(72)$ \\
\hline Occluded & $11(28)$ & $208(28)$ \\
\hline 0 & $7(18)$ & $158(21)$ \\
\hline 1 & $4(10)$ & $50(7)$ \\
\hline 2 & $5(13)$ & $156(21)$ \\
\hline 3 & $23(59)$ & $383(51)$ \\
\hline
\end{tabular}

examined, $40(4.9 \%)$ had evidence of clinical pericarditis during the hospitalization. The variability among the different phases of the thrombolytic studies was not substantial.

Baseline characteristics for patients with or without a pericardial tub did not differ with regard to gender, demographics and standard cardiac risk factors (Table III). Of the 40 cases, 23 (58\%) had a rub detected within 48 hours of initial presentation.

Patients with anterior wall AMI had a higher incidence of a pericardial friction rub than those with inferior AMI (Table IV). Similarly, the left anterior descending coronary artery was more often the infarctrelated artery in the pericarditis group. Patients who developed a friction rub had more severe coronary dis- 
ease than those who did not $(33 \%$ with 3 -vessel or left main disease versus $17 \%$ ). No difference was apparent in acute catheterization Thrombolysis in Myocardial Infarction study flow grades between those with or without clinical pericarditis:

Patients with clinical pericarditis had a significantly lower global ejection fraction at the time of acute ventriculography (Figure 1): Median global ejection fraction was $45 \%$ for those with and $51 \%$ for those without $(\mathrm{p}=0.002)$. Infarct zone function measured in SDs per chord was significantly worse at the time of catheterization in patients who developed clinical pericarditis (Figure 2). Median infarct zone function (SD per chord) was -3.2 in patients with a pericardial rub compared with $-2.7 \mathrm{SD}$ per chord in patients without a pericardial rub $(\mathrm{p}=0.024)$. Of these 2 measurements, global left ventricular ejection fraction at baseline catheterization was the most important parameter for predicting the presence or absence of a pericardial friction rub ( $\mathrm{p}=$ 0.01). This finding was independent of infarction location.

When clinical outcomes were examined, patients who developed a friction rub tended to do worse than those who did not (Table V). Hospital mortality was higher in patients with (15\%) compared with those without clinical pericarditis $(6 \%)(\mathrm{p}=0.056)$. In patients with a rub who died, power failure tended to be the predominant mechanism $(83 \%)$, whereas in patients without a rub, the cause of death was more evenly distributed between power failure $(57 \%)$ and other factors, mostly arrhythmia. No patient in either group developed a hemodynamically significant pericardial effusion or cardiac tamponade by bedside clinical evaluation. This negative finding has an upper $95 \%$ confidence limit of approximately $0.4 \%$.

\section{DISCussion}

The principal finding of this study is that the incidence of a pericardial friction rub in the setting of thrombolytic therapy for AMI is especially low compared with older studies describing conservatively treated patients. ${ }^{5} \mathrm{~A}$ pericardial friction rub was only found in $5 \%$ of all patients. In contrast, the incidence of pericarditis before the thrombolytic era has been reported to be between 7 and $20 \%$. In the recently reported Multicenter Investigation of the Limitation of Infarct Size study, in which patients did not receive thrombolytic therapy, pericarditis occurred in $20 \%$ of those enrolled. ${ }^{5}$
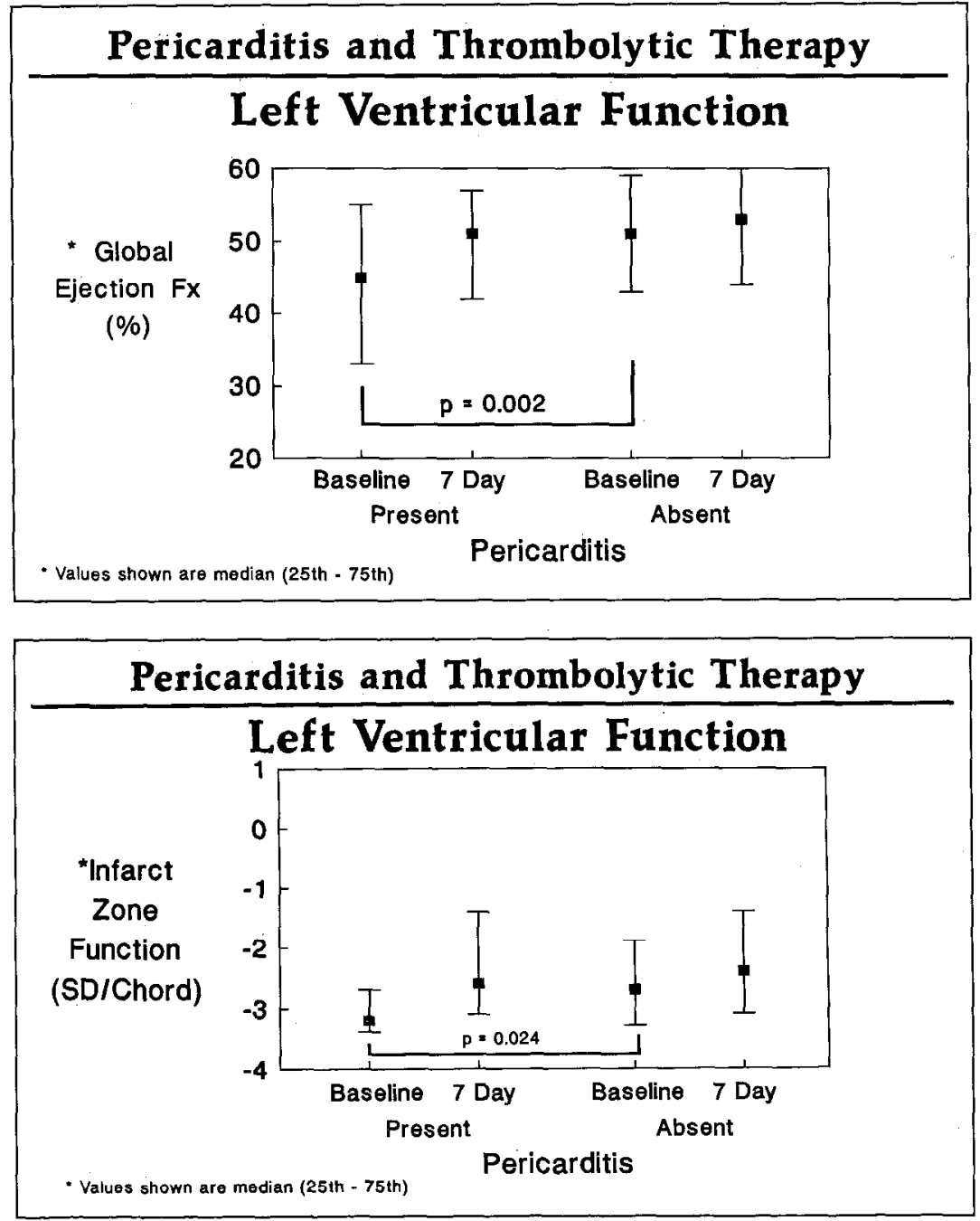

FIGURE 1. Median (25-75th percentile) values for global left ventricular function (\%) at baseline and at 7-day follow-up in patients with and without clinical pericarditis. $F x=$ fraction.
FIGURE 2. Median (25-75th percentile) infarct zone function (standard deviation [SD] per chord) at baseline and at 7-day follow-up in patients with and without clinical pericarditis. 


\begin{tabular}{|lcc|}
\hline \multicolumn{3}{|c|}{ TABLE V Major Clinical Outcomes } \\
\hline & $\begin{array}{l}\text { Pericardial Rub } \\
(\mathrm{n}=40)\end{array}$ & $\begin{array}{l}\text { No Pericardial Rub } \\
(\mathrm{n}=770)\end{array}$ \\
\hline Mortality (\%) & $6(15)$ & $49(6)$ \\
Power failure & $5(83)$ & $25(51)$ \\
Arrhythmia & $1(17)$ & $11(22)$ \\
Sudden death & 0 & $5(10)$ \\
Other & 0 & $8(16)$ \\
Congestive heart failure & & \\
Killip class (\%) & $7(18)$ & $96(12)$ \\
2 & $4(10)$ & $32(4)$ \\
3 & $1(3)$ & $11(1)$ \\
4 & $6(15)$ & $92(12)$ \\
Reocclusion & & $608(79)$ \\
Coronary artery bypass grafting & $24(60)$ & $38(5)$ \\
None & $5(13)$ & $42(5)$ \\
Emergency & $7(18)$ & $81(11)$ \\
Urgent & $4(10)$ & $1(0.1)$ \\
Elcctive & 0 & 0 \\
Late CABG & 0 & \\
Cardiac tamponade & \\
\hline CABG = coronary artery bypass graft surgery. & \\
\hline
\end{tabular}

The patients in this study who developed clinical pericarditis had more extensive myocardial damage, as documented by significantly worse baseline global and segmental left ventricular function, more frequent occurrence of anterior wall $\Lambda \mathrm{MI}$, and a higher in-hospital mortality as opposed to those without pericarditis. In fact, the degree of left ventricular damage as measured by global ejection fraction predicted the presence of a friction rub independently on infarct location. These findings are consistent with those reported before the thrombolytic era and with the pathologic findings suggesting that transmural extension of myocardial necrosis is a prerequisite for the development of a pericardial friction rub. As recently reported by Sugiura et $\mathrm{al}^{17} \mathrm{pa}-$ tients who develop pericarditis during AMI have a higher pulmonary artery wedge pressure, more advanced degrees of ventricular segmental asynergy and more often have a ventricular aneurysm. Perhaps with successful reperfusion, transmural myocardial necrosis is prevented and with it development of clinical pericarditis. This observation concurs with early canine pathologic studies by Reimer et a ${ }^{18}$ describing the wave front model of myocardial necrosis.

The low incidence of a pericardial friction rub in our study concurs with the previous thrombolytic trials for AMI. In the European Cooperative Study, pericarditis occurred in $6.3 \%$ of patients treated with recombinant tissue-type plasminogen activator as opposed to $11 \%$ of patients treated with placebo. In the Netherlands and the Italian Group for the Study of Streptokinase in Myocardial Infarction studies evaluating intravenous streptokinase versus placebo, clinical pericarditis occurred twice as frequently in patients not treated with thrombolytic therapy for AMI. ${ }^{10-12}$ These findings further support the concept that reperfusion of the infarctrelated vesscl decreases the likelihood of transmural extension of the infarct and hence the occurrence of a pericardial rub.

The fact that no patient with clinical pericarditis in this study developed clinical evidence of cardiac tam- ponade is of particular importance. This finding is even more remarkable when one considers the fact that these patients were aggressively treated with concomitant anticoagulant and antiplatelet therapy. It is certainly reassuring to know that hemopericardium with tamponade is extremely unusual in this setting despite case reports to the contrary with only heparin. ${ }^{4,8,9,19}$ We do not believe that the development of a pericardial friction rub in this setting is a contraindication for continuation of intravenous heparin.

Acknowledgment: We are most appreciative of the excellent secretarial and technical support provided by Kimberly Sue Brown and Cindy Day.

\section{REFERENCES}

1. Parkinson $J$, Bedford DR. Cardiac infarction and coronary thrombosis. Lancet 1928;1:4-11.

2. Thadani U, Chopra MP, $\Lambda$ ber COP, Portal RW. Pericarditis after acute myocardial infarction. Br Med $J 1971 ; 2: 135-137$.

3. Lichstein E, Liu H-M, Gupta P. Pericarditis complicating acute myocardial infarction: incidence of complications and significance of electrocardiogram on admission. Am Heart $J$ 1974;87:246-252.

4. Toole JC, Silverman ME. Pericarditis of acute myocardial infarction, Chest 1975;67:647-653.

5. Tofler GH, Muller JE, Stone PH, Willich SN, Davis VG, Poole K, Robertson $\mathrm{T}$, Braunwald E, and the MILIS Study Group. Pericarditis in acute myocardial infarction: characterization and clinical significance. Am Heart $J$ 1989;117:8690.

6. Kranin FM, Flessas AP, Spodick DH. Infarction-associated pericarditis. $N$ Engl J Med 1984;311:1211-1214

7. Floyd WL. Pericarditis following myocardial infarction. In: Califf RM, Wagner GS, ed. Acute Coronary Care, Principles and Practices. Boston: Martinus Nijhoff, 1985:459-461.

8. Honan MB, Harrell FE, Reimer KA, Califf RM, Mark DB, Pryor DB, Hlatky MA. Cardiac rupture, mortality, and the timing of the thrombolytic therapy: a meta-analysis. J Am Coll Cardiol 1990;16:359-367.

9. Guberman BA, Fowler NO, Engel FJ, Gueron M, Allen JM. Cardiac tamponade in medical patients. Circulation 1981;64:633-640.

10. Franzosi MG, Mauri F, Pampallona S, Bossi M, Matta F, Farina ML, Tognoni G. The GISSI study further analysis. Circulation 1987;76(II):II-53-HI56.

11. Van de Werf F and the European Cooperative Study Group. Lessons from the European cooperative recombinant tissue-type plasminogen activator (rt-PA) versus placebo trial. I Am Coll Cardiol 1988;12:14A-19A

12. Simoons ML, Brand M, DeZwaan C, Verheugt FWA, Remme WJ, Serruys PW, Bar F, Res J, Krauss XH, Vermeer F, Lubsen J. Improved survival after early thrombolysis in acute myocardial infarction. Lancet 1985;2:578-581.

13. Topol EJ, Califf RM, George BS, Kereiakes DJ, Abbottsmith CW, Candela RJ, Lee KL, Pitt B, Stack RS, O'Neill WW, TAMI Study Group. A randomized trial of immediate versus delayed elective angioplasty after intravenous tissue plasminogen activator in acute myocardial infarction. $N$ Engl $J$ Med 1987;317: $581-588$.

14. Topol EJ, George BS, Kereiakes DJ, Stump DJ, Candela RJ, Abbotsmith CW, Aronson L, Picked A, Boswick JM, Lee KL, Ellis SG, Califf RM, TAMI Study Group. A randomized controlled trial of intravenous tissue plasminogen activator and early intravenous heparin in acute myocardial infarction. Circulation 1989:79:281-286.

15. Topol EJ, Califf RM, George BS, Kereiakes DJ, Rothleum D, Candela RJ, Abbottsmith CW, Pinkerton CA, Stump DC, Collen D, Bowick JM, O'Neill WW, Stack RS, TAMI Study Group. Coronary arterial thrombolysis with combined infusion of recombinant tissue-type plasminogen activator and urokinase in patients with acute myocardial infarction. Circulation 1988;77:1100-1107.

16. Wall TC, Phillips HR, Stack TS, Mantell S, Aronson L, Boswick J, Sigmon, Dimeo M, Chaplin D, Whitconb D, Pasi D, Zawodniak M, Hajisheik M, Hedge S, Barker W, Tenney R, Califf RM. Results of high dose intravenous urokinase for acute myocardial infarction. Am J Cardiol 1990;65:124-131.

17. Sugiura T, Iwasaka T, Takayama Y, Matsutani M, Hasegawa T, Takahash $\mathrm{N}$, Inada $\mathrm{M}$. Factors associated with pericardial effusion in acute $\mathrm{Q}$-wave myocardial infarction. Circulation 1990;81:477-481.

18. Reimer KA, Lowe JE, Rasmussen MM, Jennings RB. The wave fron phenomenon of ischemic cell death. Myocardial infarct size vs duration of coronary occlusion in dogs. Circulation 1977;56:786-794.

19. Niarchos AP, McKendrick CS. Prognosis of pericarditis after acute myocardial infarction. Br Heart $J$ 1973;35:49-54.

20. Pryor DB, Harrell FE, Lee KL, Califf RM, Rosati RA. Estimating the likelihood of significant coronary artery disease. Am J Med 1983;5:771-780. 